\title{
Capital Budget Implementation in Nigeria: Evidence from the 2012 Capital Budget
}

\author{
Kanayo Kingsley Ogujiuba', Kizito Ehigiamusoe ${ }^{2}$
}

ABSTRACT

\begin{abstract}
The performance of the capital budget has been a subject of debate between the legislative and executive arms of the Nigerian government since 1999. Available statistics suggest that the annual budget has not been able to improve the lives of Nigerians over the past several years because of the weak link between capital budget implementation and poverty reduction, as indicated by the prevailing low index of capture in public expenditures. Using descriptive analysis, this paper examines the capital budget implementation in Nigeria by focusing on the 2012 Federal Government Budget. The findings indicate that only $51 \%$ of the total appropriated funds for capital expenditures were utilized as of December 31st, 2012. The observed level of performance is insufficient to foster rapid economic development and reduce poverty. Some of the challenges that are responsible for the low performance include poor conceptualization of the budget, the inadequacy of implementation plans, the non-release or late release of budgeted funds, the lack of budget performance monitoring, the lack of technical capacity among MDAs, and delays in budget passage and enactment. The paper recommends that Nigerian government formulate a realistic and credible budget, release appropriated funds early to Ministries, Departments, and Agencies (MDAs), and strengthen MDAs' technical capacity to utilize capital expenditures in order to improve the index of capture in public expenditures.
\end{abstract}

KEY WORDS: $\quad$ budget; capital budget performance; capital expenditure

JEL Classification: $\quad \mathrm{H} 61 ; \mathrm{H} 11 ; \mathrm{H} 50$

'University of Western Cape - Statistics \& Population Studies, South Africa

${ }^{2}$ National Institute for Legislative Studies, Nigeria

\section{Introduction}

The Federal Government of Nigeria has a constitutional obligation to develop a budget every fiscal year. The budget, simply put, is a statement of income and expenditures and provides an indication of the government's priorities regarding expenditures for the year.

Correspondence concerning this article should be addressed to: Kanayo Kingsley Ogujiuba, University of Western Cape - Statistics \& Population Studies Western Cape, Bellville, Cape Town 7538 South Africa, Email: kannyog@gmail.com
The national budget is the most important economic policy instrument for a government and it reflects the government's priorities regarding social and economic policy more than any other document. In addition, the instrument translates policies, campaign promises, political commitments, and goals into decisions regarding where funds should be spent and how funds should be collected. A well-functioning budget system is vital for the formulation of sustainable fiscal policy and the facilitation of economic growth (Ohanele, 2010).

Public expenditures at the local, state, and federal government levels are incurred for the purposes of 
satisfying the collective social wants of the people. Public expenditure policy aims to accelerate economic growth, promote employment opportunities, and reduce poverty and income inequality. Government expenditures can be either recurrent or capital expenditures, and governments at all levels use budgets to finance government expenditures.

The political economy of national budgets is an aspect that every nation must take seriously, particularly in the contemporary era of near financial accuracy, because of the Internet and telecommunications technology. With its population of over 150 million, effective budget monitoring and implementation remains one sure route to Nigeria's economic and socio-infrastructural rejuvenation. Thus, the budget cycle in Nigeria usually proceeds in four stages: budget formulation, during which the budget plan is established by the executive arm of government; enactment, during which the budget plan is debated, altered, and approved by the legislative arm; execution, during which the policies of the budget are implemented by the government; and auditing and assessment, during which the actual budget expenditures are accounted for and assessed for effectiveness. Each of the stages creates different opportunities for participation by the people (Ohanele, 2010).

The continued delays in budget formulation and implementation in Nigeria are worrisome. It is no longer news that unnecessary delays in passing and implementing Nigeria's national budget have continued to slow economic activities in Nigeria and prevent the implementation of projects that would enhance the quality of life of the people. These unfortunate delays have become recurring events since 1999 and have painfully slowed Nigeria's democratic journey to economic prosperity.

It must be noted that delays over the past several years have resulted in a low national budget performance and have limited the executive arm's ability to effectively execute projects that would improve the living conditions of the citizenry (Ibrahim, 2011). Furthermore, the low level of budget implementation has been a consistent problem in Nigeria. Thirteen years into the fourth republic, there has never been a year in which the capital budget attained $75 \%$ implementation.

Since 1999, there have been disagreements between the legislative arm of the government and the presidency over the budget performance. The federal government has always insisted that it is committed to the proper implementation of the annual budget, whereas the National Assembly has insisted that the federal government does not always implement the annual budget as it has been enacted. Similarly, many analysts have asserted that the rate of capital budget implementation over the past decade has varied widely; indeed, it was $50 \%$ in 2002 and $2003,52 \%$ in 2004 and 2005, 43.9\% in 2008, and 54\% in 2009 (Oladipo et al., 2012)

The capital budget therefore is the aspect of the overall national budget that determines the allocation of funds to finance capital projects and critical infrastructure, such as the construction of roads, bridges, hospitals, schools, prisons, public administrative buildings, highways, dams, and irrigation systems; the purchase of machinery and equipment; and the supply of water, electricity, and transport, health, and educational facilities. The capital budget, unlike the recurrent budget, is intended to provide funds to finance capital expenditures, such as the construction of durable assets. By contrast, the recurrent budget determines the allocation of funds to finance recurring governmental expenditures, such as expenditures related to personnel, overhead, civil administration, defense, health, education, and government machinery maintenance. For a public budget to effectively perform its role, it should be well designed, effectively and efficiently implemented, and adequately monitored, and ultimately, its performance should be evaluated (Faleti \& Myrick 2012).

Nonetheless, the environment in which the 2012 FGN budget was prepared raised Nigerians' expectations, particularly with respect to the goal of transforming the economy to the level at which the federal government has set. With gross federally collected revenue estimated at N9.406 trillion and government's expenditure projection at N4.749 trillion, up from N4.484 trillion appropriated in 2011, Nigerians had high expectations that given the transparent budget implementation, they would receive the greatest value for every kobo spent. Nigerians expected the 2012 budget to be a budget that would provide critical infrastructure (such as roads, electricity, water, schools, and hospitals) and employment, reduce poverty, and supply health, transport, and educational facilities. 
Table 1. Delays in the Preparation and Enactment of the Federal Government Budget, 2000-2013

\begin{tabular}{ccccc}
\hline $\begin{array}{c}\text { Fiscal } \\
\text { Year }\end{array}$ & $\begin{array}{c}\text { Date NASS Received the } \\
\text { Budget from President (A) }\end{array}$ & $\begin{array}{c}\text { Date Revised the Budget } \\
\text { was sent to President for } \\
\text { Assent (B) }\end{array}$ & $\begin{array}{c}\text { Date President Assented } \\
\text { to the budget (C) }\end{array}$ & $\begin{array}{c}\text { Time lag between } \\
\text { President's Presentation } \\
\text { and Signature (D) }\end{array}$ \\
\hline 2000 & 24th November, 1999 & 14th April, 2000 & 5th May, 2000 & 5 months 11 days \\
2001 & 9th November, 2000 & 21st December, 2000 & 21st Dec., 2000 & 1 month, 12 days \\
2002 & 7th November, 2001 & 28th March, 2002 & 28th March, 2002 & 4 months, 21 days \\
2003 & 20th November, 2002 & 11th March, 2003 & 10th April, 2003 & 4 months, 21 days \\
2004 & 18th December, 2003 & 20th April, 2004 & 21st April, 2004 & 4 months, 3 days \\
2005 & 12th October, 2004 & 18th March, 2005 & 12th April, 2005 & 6 months \\
2006 & 6th December, 2005 & 21st February, 2006 & 22nd April, 2006 & 2 months, 16 days \\
2007 & 6th October, 2006 & 22nd December, 2006 & 22nd December, 2006 & 2 months, 12 days \\
2008 & 8th November, 2007 & 27th March, 2008 & 14th April, 2008 & 5 months, 7 days \\
2009 & 2nd December, 2008 & 3rd February, 2009 & 10th March, 2009 & 3 months, 8 days \\
2010 & 23rd November, 2009 & 25th March, 2010 & 22nd April, 2010 & 4 months, 29 days \\
2011 & 15th December, 2010 & 25th May, 2011 & 26th May, 2011 & 5 months, 11 days \\
\hline
\end{tabular}

However, the implementation of the 2012 capital budget did not match expectations, as controversy concerning the implementation level of the 2012 Appropriation Act continues between the executive and legislative arms of the government. While the executive claimed that $56 \%$ of the budget had been released and implemented by July 20, 2012, the National Assembly submitted that less than $30 \%$ of the budget was implemented by September 30, 2012. As the debate to ascertain the level of implementation of the 2012 Appropriation Act continues, it becomes pertinent to examine the level of implementation of the capital budget in the 2012 Appropriation Act. The main objective of this paper is to answer the following question: Is the capital budget being implemented in Nigeria? Specifically, the paper seeks to examine the level of implementation of the 2012 Appropriation Act. The paper also seeks to identify the main factors that are responsible for the poor capital budget implementation in Nigeria.
Following this introduction, the remainder of the paper is divided into four sections. Section two presents the conceptual issues and reviews the related literature on capital budget implementation, section three presents the analytical framework that is adopted for this study, and section four presents the performance of the 2012 FGN Appropriation Act. The last part of the paper presents the conclusions and provides recommendations.

\subsection{Brief Review of Related Literature}

\subsection{The Impact of Capital Budget Expenditures on Economic Development}

Different forms of government expenditures and economic growth have been examined in the literature. Rizvi,Qamar and Shamim (2010) investigated the relationship between government expenditures and gross domestic product (GDP) based on modern time series econometric techniques. The paper used thirty years 
of data for the period from 1979 to 2008 and found a long-run relationship between government development expenditures and economic growth. A Granger causality test indicated that government expenditures are caused by economic growth, while an error correction model showed that there is a short-run relationship between government development expenditures and economic growth.

Pryor (1968) used government consumption expenditures to determine the impact of government expenditures on economic growth, while PeacockWiseman (1961) used total government expenditures to assess the same relationship. Goffman (1968), Musgrave (1969), Gupta (1967), and Michas (1975) used per-capita income instead of GDPt, as in Mann (1980). Wagner's law proposed by the German economist Adolph Wagner (1835-1917) predicts that the development of an industrial economy will be accompanied by an increased share of public expenditures in Gross National Product. During the last three decades, Wagner's law has been tested very intensively, particularly for the developed countries and more recently for developing countries (Rizvi et al., 2010). Lucas (1988) argued that public investment in education increases the level of human capital and that human capital constitutes a primary source of long-run economic growth. Henrekson (1993) claimed that there are three main reasons for an increase in the role of government. First, industrialization and modernization would lead to a substitution of public for private activities. Second, an increase in real income leads to an expansion of income-elastic "cultural and welfare" expenditures. Third, natural monopolies, such as railroads, have to be taken over by government because private companies would otherwise be unable to run these undertakings efficiently because it would be impossible to raise the huge financing needed to develop them.

Oluwatobi and Ogunrinola (2011) examined the relationship between human capital development efforts by the government and economic growth in Nigeria. The authors of this paper sought to determine the impact of government recurrent and capital expenditures on education and health in Nigeria and to assess their effect on economic growth. The data that were used for the study were taken from secondary sources, and the augmented Solow model was adopted. The result showed that a positive relationship exists between government recurrent expenditures on human capital development and the level of real output but that a negative relationship exists between capital expenditures and the level of real output. The authors therefore recommended that the government appropriately channel the nation's capital expenditures on education and health to promote economic growth.

A study of the joint development of government expenditures and economic growth in 23 OECD countries conducted by Lamartina and Zaghini (2007) showed that there is a structural positive correlation between public spending and per capita GDP. Thus, an increase in government spending on human capital development is expected to culminate in an increase in per capita output. Maku (2009) examined the connection between total government spending and economic growth in Nigeria over 30 years (1977-2006). The author regressed real GDP on private investment, human capital investment, government investment, and consumption spending. The result showed that human capital investment as a share of real output has a positive but statistically nonsignificant effect on the growth rate of real GDP. Maku concluded that government expenditures have had no significant influence on economic growth in Nigeria based on his analysis, which reveals that the variables have not maintained a uniform pattern over the period of study because of a persistent random shock effect on the time series. He reported that the rate of government expenditures to real GDP has been increasing since the Structural Adjustment Programme (SAP) despite having no significant contribution to economic growth in Nigeria. Maku attributed this increase to the lack of government monitoring of the contract awarding process of capital projects, the ineffective deployment of government funds to productive activities, and the lack of transparency and accountability by the government regarding government spending (Oluwatobi \& Ogunrinola, 2011)

Ogujiuba and Adeniyi (2005) examined the impact of government education expenditures on economic growth. Their results showed a statistically significant positive relationship between economic growth and recurrent expenditures on education, while the contribution of capital expenditures to economic growth was negative but not significant. Lawanson (2009) extended this study by including both health and educa- 

to poverty reduction, while government spending on budget deficit and economic and community services appeared to be responsible for increased poverty in Pakistan. The study recommended that the Government of Pakistan allocate more resources to the education and health sectors to foster the development of human capital.

Health and education are very important determinants of poverty. Educated and healthy individuals may have more opportunities to obtain better employment, which increases their earnings and helps raise their standard of living. Education is considered to be the most important way to build human capital and eradicate poverty by enhancing productivity. Health is another major form of human capital. The results of various studies have shown that there is a positive relationship between government expenditures on health and poverty reduction, as spending on health increases individuals' capabilities and thereby reduces poverty.

Improvements in health lead to increased life expectancy, which provides more opportunities for people to work and earn more income and eventually leads to poverty reduction. Government spending on both education and health are accordingly expected to have a negative impact on poverty (Asghar, et al 2012).

\subsection{Stylized Facts: Capital Budget Implementation in Nigeria}

Emphasizing the importance of capital budget implementation in the process and promotion of democracy within the territory of a nation state, Makstutis (2007) analyzed the global economic factors that drive the development of a nation state and examined the place of a nation state in the development of progress, the promotion of democracy in the territory of the state, and activation of public activity in light of globalization

The capital budget is important to the public because it is a major source of funding for capital projects. It is imperative to point out that the capital budget has a direct impact on the lives of the people in a country and that the level of capital budget implementation remains a measure of government performance (Onike, n.d.). Bak (2009) examined the current concepts of budgeting with a special focus on innovative budgets as well as the evolution of the budgeting concept and concluded that budgets constitute a primary tool for the achievement of a country's predetermined goals. It is indeed worrisome that practically every year, the implementation of the capital budget in Nigeria has been the major source of friction between the Executive and the House of Representatives. In 2010 and 2011, the Executive also accused of poorly implementing the capital budget. While further reflecting on the cause of the dispute, Onike (n.d.) opined that it is not surprising that there was no serious contention regarding the recurrent budget, as the recurrent budget mainly involves the statutory budget allocation and general costs of administration/overhead. Critics, nonetheless, recognized that in the last 13 years or so, the federal budget has never been implemented satisfactorily. Further, a credible explanation for the disbursement of the billions of naira that remained unspent at the end of each year has never been given.

Boyo (2012) asserted that Nigerians may be misguided, however, for expecting substantial improvements in social welfare resulting for the appropriate and full disbursement of the capital budget. Indeed, the seemingly traditional pattern of less than $30 \%$ allocation for capital projects cannot truly support rapid infrastructural improvement for a country of over 160 million people. Furthermore, tangible progress is further precluded by the prevalent culture of impunity and corruption, which inevitably substantially diminishes the already meager capital budget. Ayemokhia (2010) posited that Nigeria produces one of the best annual budgets in all of Sub-Saharan Africa because the nation is blessed with an intimidating array of top-class financial experts in the Central Bank of Nigeria (CBN) and ministries in charge of Finance, Planning, and Budget. However, these advantages have not helped drive Nigeria up the ladder of developing nations in the world. Such progress would nevertheless have been attained if the federal and state governments had even strived to achieve a moderate $60 \%$ budget implementation benchmark since 1999. Ayemokhia's paper suggests that over the years, poor budget implementation by the executive arm of the government at the local, state, and federal levels has impaired key public infrastructure for transport, power, and communication, among others. Accordingly, the annual budget has been condemned as a mere annual ritual in Nigeria. Furthermore, Ayemokhia (2010) posited that the poor budget implementation in Nigeria is a huge indictment on both the executive and the legislative 



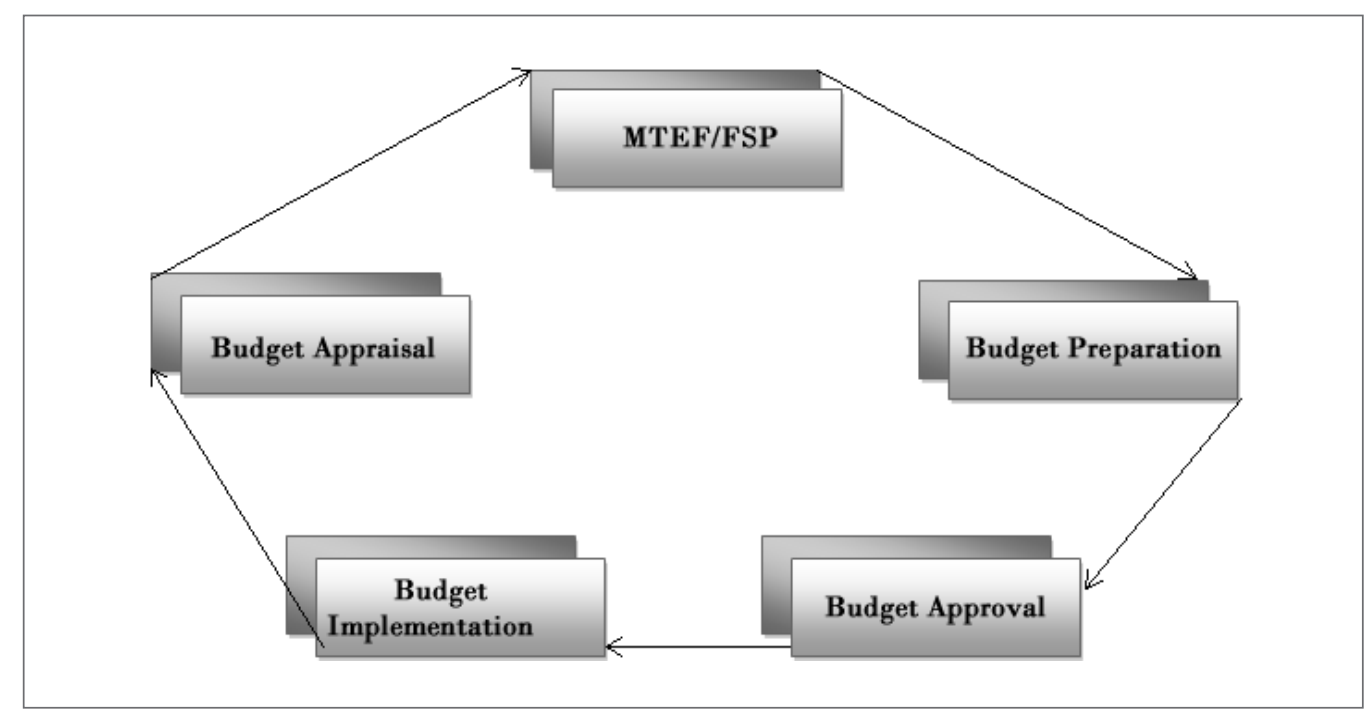

Figure 1. The Public budget Process in Nigeria

a year. It is one of the most important economic policy instruments of governments. The government budget is used to allocate resources to strategic priorities and to prevent misallocation of resources. It is also used to ensure macroeconomic stability and managerial efficiency. As a fundamental instrument of resource mobilization and allocation, the budget facilitates the realization of the vision and goals of the government in a particular fiscal year. Further, the public budget determines that allocation of resources to finance both capital and recurrent expenditures.

The budget process is an interconnected set of activities that ensure the delivery of a budget plan. In Nigeria, the public budget system begins with the preparation and approval of a three-year MediumTerm Expenditure Framework (MTEF)/Fiscal Strategy Paper (FSP) by the executive and the legislative arms of the government, respectively. The key stages in Nigeria's annual budget process include budget preparation, budget approval, budget implementation, and budget appraisal. Starting from the MTEF/FSP, figure 1 illustrates the public budget process in Nigeria.

\section{A. Medium-Term Expenditure Framework}

(MTEF)/Fiscal Strategy Paper (FSP): This is the fiscal policy framework for Nigeria envisaged by the Fiscal Responsibility Act (FRA) of 2007 to en- sure the prudent management of Nigeria's resources, promote macroeconomic stability, and foster a sustainable long-term growth path for the economy. The FRA requires the Federal Government to develop a Fiscal Strategy Paper (FSP) within a Medium-Term Expenditure Framework for a period covering three years to serve as the basis for the preparation of the estimates of revenue and expenditures for Nigeria, including government fiscal obligations in the medium term. It also provides the basis for the sectoral and compositional distribution of public expenditure estimates. Apart from providing the basis for the annual budget planning, the MTEF and FSP also set out the macroeconomic framework that indicates fiscal targets and that estimates revenue and expenditures as well as the underlying assumptions for these projections. The annual budget is therefore prepared based on these underlying assumptions and projections in the MTEF and FSP documents.

B. Budget Preparation: As soon as the MTEF and FSP documents are approved by the legislature, the next stage commences with a review of the performance of the previous year's budget. Consequently, data are collected and reviewed, accounting for political, economic, and social constraints. This back- 

of VAT, which were expected to contribute N1,992.33 billion, N355.09 billion, N230.09 billion, and N80.93 billion, respectively, to the federal government revenue. In addition, the FGN Share of the actual balance in special accounts was expected to contribute N32.33 billion for the period under review. However, the actual revenue was N1,933.61 billion (representing 97.1\% of the expected figure) for the share of the federation account, N122.37 billion (representing 34.5\% of the expected figure) for independent revenue, N70.74 billion (representing $87.4 \%$ of the expected figure) for the share of VAT, N27.389 billion (representing 11.9\% of the expected figure) for unspent funds from the previous year, and N40.93 billion (representing 126.6\% of the expected figure) for the FGN share of the actual balance in special accounts.

\subsection{Recurrent Expenditure performance}

The 2012, the recurrent budget was not expansionary with regard to fiscal consolidation. The projected level of recurrent expenditures was N3,357.22 billion-or $0.6 \%$ higher than the 2011 budgeted recurrent expenditures of N3,337.99 billion. Generally, there was slight over-performance in the actual level of recurrent expenditures, which was N3,143 billion (representing $105.3 \%$ of the appropriated figure of N2,984 billion, with a difference of N159 billion). A further breakdown of recurrent expenditures shows that capital budget releases for personnel costs, overhead costs, and statutory transfers accounted for N1,974 billion (representing 109\% of appropriated figure of N1,799 billion), N491 billion (representing 128\% of appropriated figure of N381 billion), and N678 billion (representing $111.7 \%$ of appropriated figure of N607 billion), respectively, of recurrent expenditures. This analysis shows that there was a general over-performance of recurrent expenditures (105.3\% of appropriated funds).

\subsection{Capital Expenditure Performance}

Despite the revenue and recurrent expenditure performance, which were $96.1 \%$ and $105.3 \%$, respectively, by December 2012, the capital budget performance during the same period was poor. The approved level of capital expenditures was N1,343.99 billion, which was about 17.2\% higher than the 2011 figure; however, the actual level of capital expenditures was only N686.3 billion-or $51 \%$ of the approved estimate (see
Table 1). The amount cash backed during the period was N739.3 billion, while the MDA balance was N53 billion. However, the detailed capital budget performance of MDAs, as measured by the ratio of capital utilization to the amount cash backed of total capital budget releases, was relatively unsatisfactory. Specifically, on average, the ratio of capital utilization to the amount cash backed of total releases was $51 \%$. Thus, although only about $25 \%$ of the capital budget had not been released by December 31st, 2012, half of the capital funds allocated for MDAs were not utilized in 2012. Therefore, the capital budget performance for 2012 measured as the ratio of cash utilization by MDAs to the total appropriation for MDAs was very poor. This underperformance resulted from poor implementation of capital projects/programs, and the main reasons for this poor performance include weak conceptualization of projects; inadequate cost determination, planning, and management of projects; non-release of adequate capital funds to MDAs; late release of paltry funds to MDAs, and non-utilization of released funds by MDAs, among others.

The performance of MDAs in terms of capital budget releases and utilization is mixed because some MDAs performed well in relation to their releases, while others performed poorly. For instance, Table 2 shows the MDAs that recorded the highest percentage of capital budget releases. The highest percentage of capital budget releases was recorded by the Presidency $(86.7 \%)$, followed by Defense (82.5\%), Foreign Affairs (80.4\%), Works (78.7\%), FCTA (76.8\%), Aviation $(76.7 \%)$, and Health $(73.8 \%)$. The MDAs that recorded the lowest percentage of capital releases include Youth Development (60.8\%), Housing (64.6\%), Petroleum (65.1\%), Transport (67.2\%), and Science \& Technology (67.9\%). In terms of funds utilization, Works, Defense, and Petroleum recorded the highest level of funds utilization at $99.8 \%, 76.9 \%$, and $75.5 \%$, respectively, while the MDAs that recorded the lowest level of funds utilization include ICPC (33.8\%), Trade \& Investment (42.3\%), Labor \& Productivity (44.9\%), Women Affairs (46.5\%), Mines \& Steel (46.4\%), Justice (47.9\%), and Science \& Technology (47.9\%). It is important to note that human capital development was not given priority in the budget because of the budgeted figures for Education and Health, the utilization rates were $52.1 \%$ and $55.3 \%$, respectively. These levels 
Table 2. Capital Expenditure Performance of MDAs as of December 31st, 2012 (N'Billion)

\begin{tabular}{|c|c|c|c|c|c|c|c|}
\hline MDAs & $\begin{array}{c}2012 \\
\text { Appropriated } \\
\text { (Jan-Dec) }\end{array}$ & $\begin{array}{c}2012 \text { Actual } \\
\text { Releases } \\
\text { (Jan-Dec) }\end{array}$ & $\%$ Released & $\begin{array}{c}\text { Amount } \\
\text { Cashed Back }\end{array}$ & $\begin{array}{c}\text { MDAs } \\
\text { Balance @ } \\
\text { Dec. 31st, } \\
2012 \\
\end{array}$ & $\begin{array}{l}\text { Amount } \\
\text { Utilized }\end{array}$ & $\%$ Utilized \\
\hline Presidency & 15.66 & 13.57 & 86.7 & 12.02 & 0.29 & 11.73 & 74.9 \\
\hline SGF & 32.73 & 21.82 & 66.7 & 16.23 & 5.56 & 10.67 & 32.6 \\
\hline Youth Devt & 7.15 & 4.35 & 60.8 & 3.33 & 0.36 & 3.32 & 46.4 \\
\hline Agriculture & 48.19 & 32.47 & 67.4 & 26.4 & 0.25 & 26.14 & 54.2 \\
\hline $\begin{array}{c}\text { Water } \\
\text { Resources }\end{array}$ & 79.33 & 55.56 & 70.0 & 39.76 & 0.54 & 39.22 & 49.4 \\
\hline Defence & 45.44 & 37.49 & 82.5 & 37.49 & 3.16 & 34.33 & 75.5 \\
\hline Education & 66.83 & 47.59 & 71.2 & 36.46 & 1.62 & 34.83 & 52.1 \\
\hline Health & 60.95 & 45.00 & 73.8 & 37.17 & 3.49 & 33.68 & 55.3 \\
\hline Power & 75.49 & 52.03 & 68.9 & 41.10 & 1.55 & 39.55 & 52.4 \\
\hline Works & 159.46 & 125.57 & 78.7 & 125.43 & 14.08 & 125.29 & 99.8 \\
\hline Transport & 46.86 & 31.51 & 67.2 & 26.94 & 2.92 & 24.02 & 51.5 \\
\hline Mines \& Steel & 3.17 & 1.98 & 62.5 & 1.50 & 0.37 & 1.47 & 46.4 \\
\hline Aviation & 43.16 & 33.10 & 76.7 & 31.01 & 0,59 & 30.95 & 71.7 \\
\hline FCTA & 46.26 & 35.53 & 76.8 & 33.37 & 0.14 & 33.36 & 72.1 \\
\hline Foreign Affairs & 7.45 & 5.99 & 80.4 & 5.28 & 0.43 & 5.23 & 70.2 \\
\hline Interior & 7.56 & 5.12 & 67.7 & 4.21 & 0.10 & 4.2 & 55.5 \\
\hline Petroleum & 8.13 & 5.29 & 65.1 & 3.98 & 2.25 & 1.73 & 76.9 \\
\hline Science \& Tech & 27.31 & 18.57 & 67.9 & 13.15 & 0.76 & 13.07 & 47.9 \\
\hline Others & 642.71 & 320.19 & 49.8 & 245.17 & 14.54 & 213.44 & 33.2 \\
\hline Grand Total & $1,345.19$ & 1,017 & 75.6 & 739.3 & 53.0 & 686.3 & 51.0 \\
\hline
\end{tabular}

Note: Data source: Office of the Accountant General of the Federation (OAGF).

of funds utilization are not capable of accelerating poverty reduction in Nigeria. Figures 1, 2, and 3 show the levels of capital funds that were appropriated, released, and utilized by some MDAs in Nigeria in both nominal and percentage terms.

\subsection{Factors Affecting Capital Budget Implementation in Nigeria}

Several factors were observed to be responsible for the poor capital budget implementation in Nigeria:

(i) Inappropriate Budget Formulation: Several factors are responsible for inappropriate budget formulation in Nigeria, and they include inappropriate planning by MDAs, inadequate review by the Budget Office, amendments to the budget by the National Assembly, overloading of MDAs' budgets, inadequate funds allocated to some ongoing projects, and over budgeting. If the budget is not well formulated, it is difficult to implement capital projects.

(ii) Problem of Budget Preparation: Faulty budget preparation in Nigeria has contributed to the problem of capital budget implementation. In several instances, projects that were submitted during budget formulation were not prepared for processing or procurement by the time the budget was approved. In addition, delays arise where one MDA relies on another MDA to prepare a project document after budget approval. 


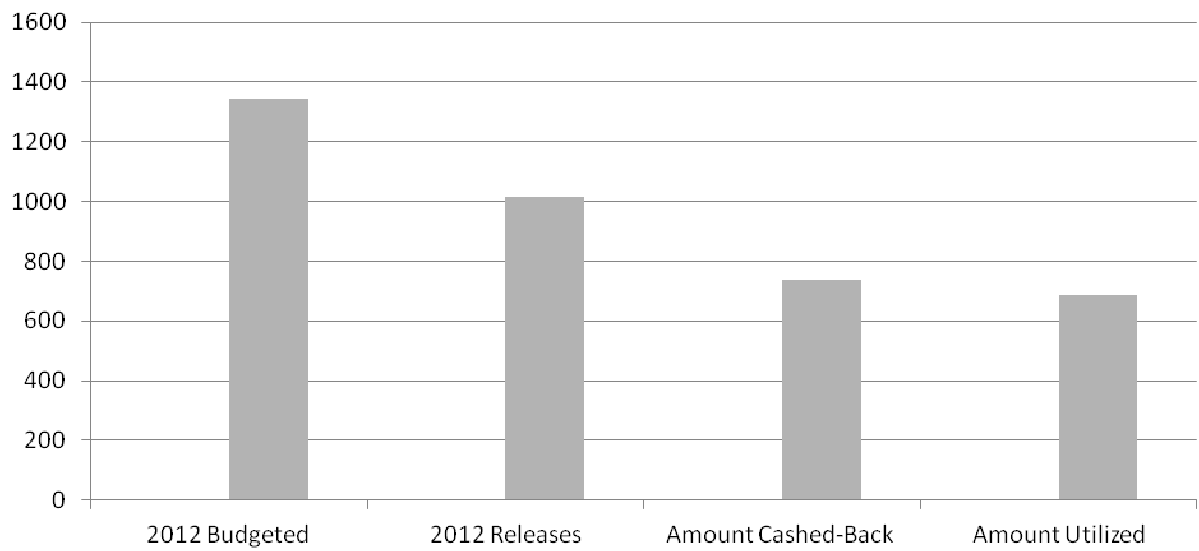

Figure 2. Budgeted, Released, and Utilized Capital Funds in the 2012 FGN Budget as of December 2012

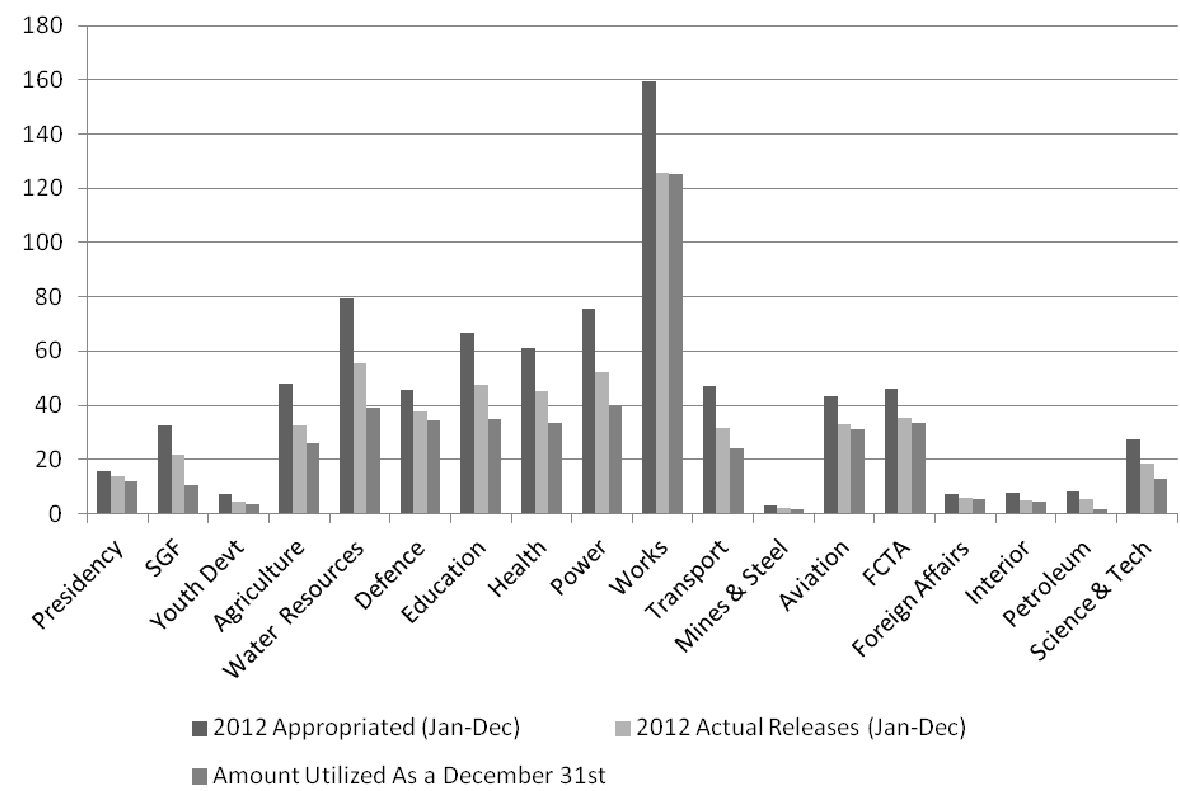

Figure 3. Budgeted, Released, and Utilized Capital Funds in the FGN Budget as of December $31^{\text {st }} 2012$ 


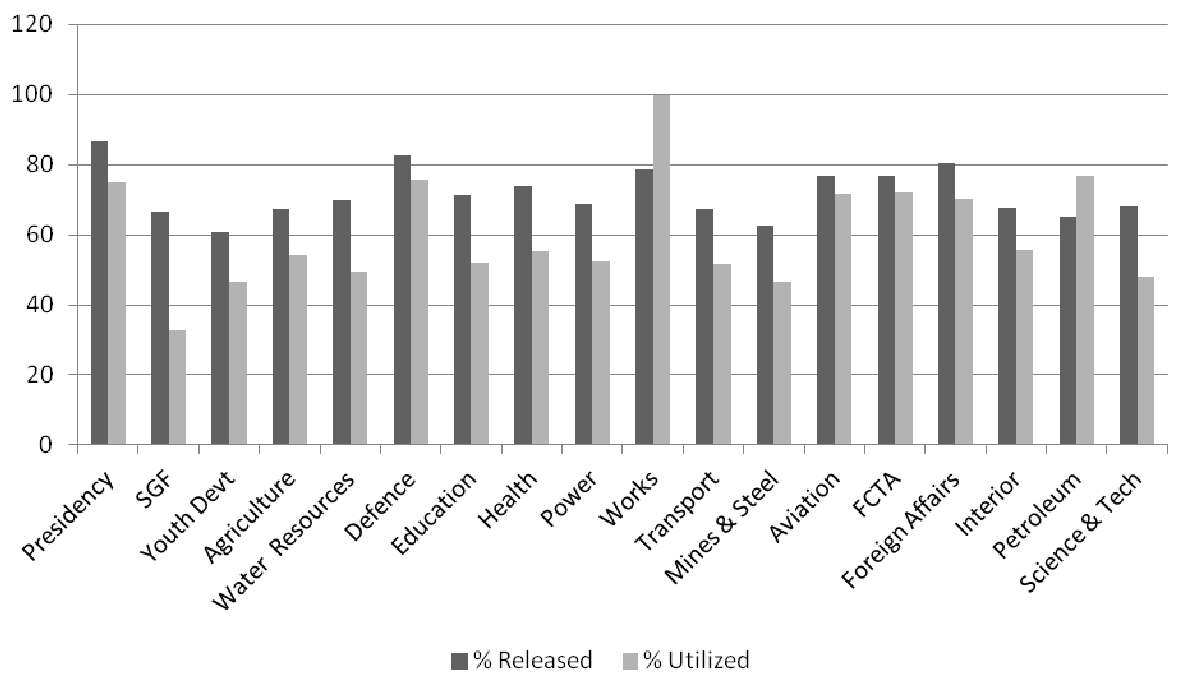

Figure 4. Percentage of Capital Funds Released and Utilized by Some MDAs as of December 2012

(iii) Budget Enactment impediments: The disagreements between the executive and the legislative arms of the government in Nigeria in recent times have often impeded the enactment of the budget. The implication of late budget enactment is that only a few months are left for budget implementation, which hinders project implementation.

(iv) Late Release or Non-Release of budgeted Funds: To implement the capital budget, budgeted funds need to be released promptly and adequately to the MDAs to operate. Irregular and uncertain release of funds is a key factor in the poor capital budget implementation in Nigeria. Sometimes, revenue shortfall is the cause, but the implications include delays in initiating and completing projects and the abandonment of projects.

(v) Problem of Cash-flow Management: The problem here is that the quarterly release of capital funds had been tied to projects. However, such release to projects tends to be inadequate in some cases to execute projects entailing huge procurements.

(vi)Challenges associated with the Due Process Mechanism and Public Procurement Act: The challenges associated with the due process mechanism and Public Procurement Act have led to serious setbacks in capital budget implementation in Nigeria. The due process mechanism and Public Procurement Act are major reforms designed to purify the public procurement process by eliminating waste and corruption. However, there has been institutional resistance, and the reform to the due process mechanism has resulted to some sort of blackmail from interested quarters. Furthermore, some MDAs have found it uncomfortable to comply with the due process requirements. There have been some genuine complaints related to delays. These arise from the time involved in the verification and certification of projects and in the processing of requests for payment.

(vii) Problem of Technical Capacity: Many MDAs in Nigeria do not have adequate technical capacity to implement the capital budget in Nigeria. These pose significant constraints to MDAs' budget implementation, particularly regarding the procurement of workers and sophisticated goods and the preparation of project documents related to works. 
(viii) Inadequacy of Implementation Plans: Implementation plans are often inadequate in terms of the steps and procedures to systematically guide capital budget implementation. Often, the government commits to allocate resources to projects without properly assessing the required results. Further, rational for prioritizing projects in the face of dwindling resources is lacking; thus, funds are channeled to the projects that can be completed and that can have a maximum impact.

(ix) Late Budget Implementation Initiative: This is a serious challenge in capital budget implementation in Nigeria because many MDAs do not have adequate capacity to implement the capital budget. In addition, the late passage of the capital budget coupled with issues surrounding the due process mechanism and Public Procurement Act further compound the capital budget implementation.

(x) Lack of adequate Budget Performance Monitoring: Mechanisms for monitoring and evaluating the budget process in Nigeria are not adequate. Although several agencies claim to assess and evaluate the performance of the budget periodically, a countless number of projects are either delayed or abandoned.

(xi) Changes in the Policy for Disbursing Capital Funds beyond the Fiscal Year: Another serious problem hampering capital budget implementation in Nigeria is the policy of disbursing capital funds beyond the fiscal year. For instance, this policy aided capital budget implementation in 2005 and 2006, but the legality of the policy is questionable. Therefore, the government has abandoned it since 2007. There is a need for MDAs to adjust to the change in policy and to focus on how to overcome the obstacles of capital budget implementation in order to accelerate the pace of budget implementation.

\subsection{Conclusion and Recommendations}

The paper examines the level of capital budget implementation by the Federal Government of Nigeria. Our findings indicate that the level of capital budget implementation in Nigeria since the advent of democracy in 1999 has been low. There has been wide disparity between budgeted capital expenditures and actual capital expenditures. Specifically, the 2012 FGN capital budget implementation was abysmal. The total capital budget released as of December 2012 as a percentage of the total appropriated capital expenditure was only $75.6 \%$, whereas the percentage of capital budget implementation was only $51 \%$. Thus, $49 \%$ of the 2012 FGN capital budget had not been implemented as of December 31 st, 2012 , while $25 \%$ of capital budget expenditures had not been released.

In contrast to capital budget expenditures, the budget for recurrent expenditures has generally been fully implemented in Nigeria since 1999. The challenges confronting capital budget implementation in Nigeria to include weak conceptualization of projects, nonrelease/late release of funds, lack of implementation plans, lack of technical capacity among MDAs, lack of a commitment to budget implementation, inadequate monitoring of budget performance, and delays in budget enactment.

This paper therefore makes the following recommendations: (i) Because the problem of budget implementation may reflect a poorly formulated budget, Nigeria needs to formulate a realistic and credible budget, as the processes of budget formulation and implementation are interdependent. (ii) Capital budget funds should be released early by the Federal Ministry of Finance to the Ministries, Departments, and Agencies (MDAs) in order to accelerate budget implementation in Nigeria. (iii) Since poor capital budget implementation may reflect a lack of incentives for good budget implementation rather than a lack of capacity, the government should create incentives for compliance and enforce punishment for non-compliance by Ministries, Departments, and Agencies (MDAs). (iv) Furthermore, the government should reduce wasteful nondevelopment-related spending financed through domestic and foreign borrowing and allocate more resources for the development of the education, health, and infrastructure sectors of the economy. (v) The capacity of Ministries, Departments, and Agencies (MDAs) to utilize funds released to them should be strengthened. Finally, there is a need to address the challenges confronting capital budget implementation in Nigeria by improving the index of capture, which is currently abysmally low. 


\section{References}

Akande, S. O., Falokun, G. O., Taiwo, S. O., Ogunwale, A. O \& Adeoye, B. W. (2009). Budget Process in Selected Countries: Lessons for Nigeria (Monograph Series, No.8). Nigerian Institute for Social and Economic Research.

Asghar, N., Hussain, Z. \& Rehman, H. (2012). The Impact of Government Spending on Poverty Reduction: Evidence from Pakistan 1972-2008. African Journal of Business Management, 6 (3), 845-853.

Ayemokhia, A. (2010, April 3). Budget Implementation is Key to Nigeria's Recovery. Thisday Newspaper, pp. 14-16.

Bąk, A. (2009). Innovative Concepts of Budgeting in the Enterprises. Contemporary Economics, 3 (1), 65-73.

Bivainis, J. \& Butkevicius, A. (2003). Methodological Aspects of Evaluation of State Budget Programmes. Journal of Business Economics and Management, 4 (1), 53-61.

Boyo, H. (2012, August 10). Capital Budget Imbroglio and Subsidy: The Punch Newspapers, pp. 3-4.

Faleti, K. O. \& Myrick, D. (2012). The Nigerian Budgeting Process: A Framework for Increasing Employment Performance. Mediterranean Journal of Social Sciences, 3 (12), 193-213.

Fan, S., Hazell, P. \& Thorat, S. (2000). Government Spending, Growth and Poverty in Rural India. American Journal of Agricultural Economics, 82 (4), 1038-1051.

Fan, S., Zhang, L., \& Zhang, X. (2002). Growth, inequality, and Poverty in Rural China: The Role of Public Investment (Research Report No.125). International Food Policy Research Institute.

Goffman, I. J. (1968). On the Empirical Testing of Wagner's Law: A Technical Note. Public Finance, 23 (3), 359-364.

Golenko-Ginzburg, D., Laslo, Z., Ben-Yair, A., \& Baron, A. (2006). Optimizing Budget Allocation among Project Activities. Journal of Business Economics and Management, 7 (1), 17- 20.

Gomanee, K., Morrissey, O., Mosley, P., \& Verschoor, A. (2005). Aid, Government Expenditure and Aggregate Welfare. World Development, 33 (3), 355-370.

Gupta, S. P. (1967). Public Expenditure and Economic Growth: A Time Series Analysis. Public Finance, 22 (4), 423-466.
Henrekson, M. (1993). Wagner's Law, A Spurious relationship, Public Finance, 48 (3), 406-415.

Ibrahim, H. (2011, May 28). Of Budget Delay, Implementation and National Planning. Nigerian Tribune Newspapers, pp. 6-7.

Jung, H. S., \& Thorbecke, E. (2003). The Impact of Public Education Expenditure on Human Capital, Growth, and Poverty in Tanzania and Zambia: a General Equilibrium Approach. Journal of Policy Modeling, 25 (8), 701-725.

Jung, S., Seong-Hoon, C. \& Roberts, R. (2009, January $31^{\text {st }}$-February $\left.3^{\text {rd }}\right)$. Public Expenditure and Poverty Reduction in the Southern United States. Paper presented at the Southern Agricultural Economics Association Annual Meeting, Atlanta, Georgia.

Kocurek, K. (2008). Sources Evolution of Budget Deficit's in Poland Subject to Push-Out Effect. Contemporary Economics, 2 (3), 21-30.

Lamartina, S. \& Zaghini, A. (2007). Increasing Public Expenditures: Wagner's Law in OECD Countries. German Economic Review 12 (2), 149-164.

Lawanson, O. I. (2009). Human Capital Investment and Economic Development in Nigeria. The Role of Education and Health. Oxford Business and Economics Conference, June $24^{\text {th }}-26^{\text {th }}$. Oxford University.

Lucas, R. E. (1988). On the Mechanics of Economic Development, Journal of Monetary Economics, 22 (1), 3-42.

Lipton, M \& Ravallion, M. (1995). Poverty and Policy. In H. Chenery \& T. N. Srinivasan (Eds.), Handbook of Development Economics (Vol. 3) (pp. 25512657). Amsterdam: North Holland.

Maku, O. E. (2009). Does Government Spending Spur Economic Growth in Nigeria? (Working Paper No. 17941). Munich Personal RePEc Archive.

Makstutis, A. (2007). The Problems of Development of National State. Journal of Business Economics and Management, 8 (1), 63-68.

Mann, A. J. (1980). Wagner's Law: An Econometric Test for Mexico. National Tax Journal, 33 (2), 189201.

Michas, N. A. (1975). Wagner's Law of Public Expenditure: What is the Appropriate Measurement for a Valid Test. Public Finance, 30 (1), 77-84.

Musgrave, R. A. (1969). Fiscal Systems. New Haven, CT: Yale University Press. 
Ogujiuba, K. K. \& Adeniyi, A. O. (2005). Economic Growth and Human Capital Development: The Case of Nigeria (Working Paper No. 0508023). Swedish Business School; Orebro University.

Ohanele, J. C. (2010, April 27). Government Budgets in Nigeria: Who benefits? The Punch Newspaper, pp. 6-7.

Olapido, O., Anaro, B., Anthony-Uko, N. \& Idowu B. (2012, February 8). Experts Back Senate on Budget Implementation, Leadership Newspapers, p.10.

Olurankinse, F. (2012). Analysis of the Effectiveness of Capital Expenditure Budgeting in the Local Government System of Ondo State, Nigeria. Journal of Accounting and Taxation, 4 (1), 1-6.

Oluwatobi, S. O., \& Ogunrinola, I. O. (2011). Government Expenditure on Human Capital Development: Implications for Economic Growth in Nigeria. Journal of Sustainable Development, 4 (3), 72-80.

Onike, R. (n.d.). Crying over Poor Implementation of Capital Budget in Nigeria. Retrieved from www. gamji.com/article9000/NEWS9759.htm

Peacock, A. T. \& Wiseman, J. (1961). The Growth of Government Expenditure in the United Kingdom; Princeton, NJ: Princeton University Press.

Pryor, F. L. (1968). Public Expenditure in Communist and Capitalist Nations. London, UK: George Allen and Unwin Publishers.

Rizvi, S. Z. A., Qamar, Z. \& Shamim, A. (2010). Impact of Development Spending on Economic Growth

Measuring the Effectiveness of Fiscal Policy in Sindh. Pakistan Business Review, 12 (3), 588-600. 